\title{
PENINGKATAN KEMAMPUAN KONEKSI MATEMATIKA KELAS IV MELALUI MODEL OPEN ENDED BERBANTUAN MINIATUR RUMAH ADAT KUDUS
}

\author{
Yulianti Elly Lestari $^{1 \bowtie}$, Ratri Rahayu ${ }^{2}$ dan Himmatul Ulya ${ }^{3}$ \\ ${ }^{1}$ Prodi Pendidikan Pendidikan Guru Sekolah Dasar, Universitas Muria Kudus \\ ${ }^{2,3}$ Prodi Pendidikan Pendidikan Matematika, Universitas Muria Kudus
}

\begin{tabular}{|c|}
\hline Info Artikel \\
\hline $\begin{array}{l}\text { Sejarah Artikel: } \\
\text { Diterima 25Agt } 2018 \\
\text { Direvisi 4 Sept } 2018 \\
\text { Disetujui 29 Okt } 2018\end{array}$ \\
\hline $\begin{array}{l}\text { Keywords: Mathematical } \\
\text { Connection, the Miniature } \\
\text { of Kudus Traditional } \\
\text { House, Open Ended }\end{array}$ \\
\hline
\end{tabular}

Paper type:

Research paper

\begin{abstract}
This research aimed to describe the improvement of the students' mathematical connection, students' learning ability in identifying the relationship of interlinear by using concrete model, and also to describe the teacher's teaching skill in implementing open ended model by using the miniature of Kudus traditional house on the fifth grade students of SD 1 Gondosari in the second semester, academic year 2017/2018. This research is a classroom action research that consists of two cycles. For each cycle consist of planning, action, observation and reflection. The methods of collecting the data that are used are test, interview, observation, and documentation. The instruments that are used are test question for each cycle, manual interview, and then observation sheet of the students' learning achievement and observation sheet of the teacher's teaching skill. The data would be analyzed both of quantitatively and qualitatively. The result of this research showed that the students', ability of mathematical connection which can be seen from the test of mathematical connection showed an improvement. The mean score of the students' mathematical connection test which has been teaching by implementing open ended model using the miniature of Kudus traditional house got 63.33 and the percentage of classical completeness reached $31.11 \%$. On cycle II the classical mean score improved to 78.18 and the percentage of classical completeness improved to $93.33 \%$. Then for the students' learning achievement in identifying the relationship of interlinear by using concrete model on cycle I got the mean score 2.33 (moderate) and it improved to 3.43 (excellent) on cycle II.
\end{abstract}




\section{PENDAHULUAN}

Matematika merupakan salah satu mata pelajaran yang paling tidak disukai dan ditakuti oleh siswa. Siswa memerlukan matematika untuk memenuhi kebutuhan praktis dan keterampilan penerapan matematika untuk memecahkan masalah dalam kehidupan sehari-hari. Kebanyakan siswa sebelum mempelajari matematika, sudah memiliki mindset bahwa matematika sulit untuk dipelajari, sehingga mengakibatkan siswa cenderung tidak senang dengan pelajaran tersebut.

Matematika juga dianggap sebagai pembelajaran yang membosankan dan terkesan rumit. Hal tersebut membuat munculnya berbagai pengertian tentang matematika, baik dipandang dari sisi pengetahuan maupun pengalaman dari masing-masing individu yang berbeda. Apabila dicermati, dalam kegiatan sehari-hari setiap orang akan terlibat dengan matematika, mungkin dalam bentuk sederhana, bersifat rutin maupun yang sangat kompleks (Sumarmo, 2013:2). Matematika juga dapat diartikan sebagai suatu bidang studi hidup, karena hakikat matematika adalah pemahaman terhadap pola perubahan yang terjadi di dalam dunia nyata dan pikiran manusia serta keterkaitannya. Setiap orang yang dalam kesehariannya belajar matematika, baik itu mengerjakan soal latihan maupun memahami konsep hingga aplikasinya, dapat dipastikan mereka mampu memahami materi secara tuntas (Daryanto, 2013: 155).

Kemampuan koneksi matematik adalah kemampuan mencari dan memahami hubungan berbagai representasi konsep, topik dan prosedur matematika, menerapkan matematika dalam bidang lain atau kehidupan sehari-hari, dan memahami representasi ekuivalen suatu konsep matematika (Sumarmo (2013:77)). Konsep, idea, dan prosedur matematis yang telah diperoleh dapat dikembangkan dan digunakan untuk menyelesaikan masalah yang ditemukan/dihadapi pada mata pelajaran matematika/disiplin ilmu lainnya.

Kumalasari dan Putri (2013:9), menjelaskan bahwa kemampuan koneksi matematika sangat diperlukan oleh siswa sejak dini, karena melalui koneksi matematik siswa akan memiliki pandangan dan pengetahuan yang semakin luas terhadap matematika. Konteks matematika dengan kehidupan sehari-hari, mata pelajaran lain, dan antar topik matematika dipilih karena pembelajaran akan lebih bermakna jika siswa dapat melihat masalah yang nyata dalam pembelajaran. Siswa akan lebih mudah mempelajari matematika dan memperdalam pengetahuannya jika melihat penerapan di dunia nyata.

Berdasarkan penelitian yang dilakukan oleh Bintoro dan Zuliana (2013), pembelajaran matematika di SD saat ini masih berpusat pada guru (teacher center) dengan alasan pembelajaran matematika memiliki banyak kompetensi yang harus dikuasai dan dicapai oleh siswa. Menurut Noviarny (2018) menyebutkan bahwa pembelajaran matematika di sekolah dasar masih secara konvensional, dengan komunikasi yang terbatas, dan siswa menjawab pertanyaan dari guru hanya dengan jawaban yang singkat. Siswa mengontruksikan pengetahuannya kurang maksimal. Seharusnya, guru memanfaatkan potensi keunggulan lokal Kudus yang bisa dijadikan sebagai sumber belajar siswa.

Siswa SD 1 Gondosari mengalami kesulitan dalam belajar matematika. Hasil tes pra siklus yang dilakukan di SD 1 Gondosari menunjukkan rata-rata nilai mencapai 67,4 dengan predikat cukup. Jumlah siswa yang memperoleh nilai tuntas sebanyak 18 siswa, dan yang tidak tuntas mencapai 27 siswa. Soal yang diujikan kepada siswa sesuai dengan indikator dari koneksi matematika. Rata-rata skor indikator koneksi matematika mencari hubungan berbagai representasi konsep dan prosedur mencapai 89, sedangkan indikator menggunakan koneksi antar topik matematika dengan topik lain mencapai skor ketuntasan 87, indikator koneksi matematika kedua yaitu mencari koneksi satu prosedur ke prosedur lain dalam representasi yang ekuivalen siswa memperoleh skor ketuntasan mencapai 75, pada indikator memahami representasi ekuivalen konsep atau prosedur yang sama siswa memperoleh skor 72 , indikator koneksi lainnya yaitu memahami hubungan antar topik matematika dengan mendapatkan skor ketuntasan mencapai 50, sedangkan indikator menggunakan matematika dalam bidang studi lain atau kehidupan seharihari memperoleh skor paling rendah karena hanya mencapai 43. Berdasarkan hasil tersebut, indikator koneksi matematika tidak sepenuhnya tercapai. Indikator memahami hubungan antar topik matematika, dan menggunakan matematika dalam bidang studi lain atau kehidupan seharihari memperoleh skor per indikator di bawah 75, maka dapat disimpulkan bahwa kemampuan koneksi matematika yang dimiliki siswa kelas IV perlu bimbingan.

Hasil wawancara dengan guru dan siswa kelas IV SD 1 Gondosari, diketahui bahwa dalam pembelajaran matematika minat dan kemampuan belajar yang dimiliki siswa masih rendah. 
Beberapa siswa tidak menyukai pelajaran matematika, karena cara guru menyampaikan materi pelajaran kadang membuat siswa bingung. Siswa juga kurang memahami materi matematika, karena guru menyampaikan materi matematika dengan ceramah dan dijelaskan di papan tulis. Hal tersebut selaras dengan pendapat Mardiah, Widyastuti, dan Rinaldi (2018) yang menyatakan bahwa dalam pembelajaran matematika, siswa sulit memahami materi pelajaran sehingga nilai belajar siswa rendah.

Hasil pengamatan aktivitas belajar siswa di kelas 4 SD 1 Gondosari yang berjumlah 45 siswa pada hari Sabtu, 11 November 2017. Aktivitas belajar matematika di kelas menunjukkan bahwa dalam hal membaca materi matematika, mengajukan pertanyaan, dan menjawab pertanyaan secara lisan yang berkaitan dengan materi matematika siswa kurang antusias, namun dalam hal mendengarkan, mencatat materi, dan memberikan perhatian serta konsentrasi terhadap tugas yang diberikan, siswa terlihat antusias. Keaktifan dalam diskusi kelompok kurang, karena siswa cenderung menjawab permasalahan secara individu. Siswa berani untuk mengemukakan tanggapan terhadap perbedaan pendapat, namun harus melalui pengarahan dari guru dan dengan cara serentak. Beberapa siswa juga kurang memperhatikan guru dalam menyampaikan materi pada pembelajaran matematika. Siswa terlihat antusias saat mengerjakan soal tetapi kurang mengerti jawaban dari soal yang diberikan, akibatnya pada akhir pembelajaran siswa merasa kesulitan untuk menyimpulkan materi pelajaran yang dipelajari.

Kesulitan belajar matematika siswa ditunjukkan oleh adanya hambatan-hambatan tertentu, sehingga pada akhirnya dapat menyebabkan kemampuan koneksi matematika yang dicapai di bawah Kriteria Ketuntasan Minimal (KKM). Hal tersebut merupakan salah satu dampak dari metode pembelajaran yang digunakan oleh guru dalam pembelajaran di sekolah.

Tindak lanjut dari masalah tersebut, diperlukan perbaikan proses pembelajaran yang dilakukan guru yaitu dengan menerapkan model pembelajaran open ended berbantuan miniatur rumah adat Kudus yang dapat meningkatkan kemampuan koneksi matematika siswa. Model pembelajaran open ended atau yang dikenal dengan pembelajaran terbuka merupakan pembelajaran efektif yang melibatkan pengalaman yang nyata dengan hal yang siswa jumpai dan pelajari di kehidupan sehari-hari. Dalam pembelajaran model open ended, konteks dan pengalaman merupakan hal penting untuk dipahami, pembelajaran sangat efektif dan dapat melibatkan pengalaman yang kaya dan konkret dengan menjumpai, membentuk, dan mengubah teori-teori secara praktis di lapangan (Huda, 2013: 279). Selain itu, pembelajaran open ended dapat memberikan kesempatan kepada siswa untuk dapat memahami suatu gagasan daripada sekedar melalui pengajaran langsung. Hal ini senada dengan pendapat Ulya dan Rahayu (2018) bahwa pembelajaran open ended merupakan pembelajaran yang dapat digunakan untuk membimbing siswa belajar lebih aktif dan menyenangkan.

Hasil penelitian Ulya dan Rahayu (2018) menunjukkan bahwa dibutuhkan perangkat pembelajaran open ended berbasis keunggulan lokal untuk meningkatkan kemampuan matematis siswa. Hal ini berarti dalam pembelajaran matematika siswa dapat memiliki kesempatan untuk melakukan eksplorasi dengan menggunakan pengetahuan dan keunggulan lokal di sekitarnya pada saat pembelajaran matematika.

Hasil penelitian Ulya (2016) menunjukkan bahwa pembelajaran matematika belum menerapkan dan memberikan pemahaman terhadap pentingnya nilai budaya. Hal ini sebagaimana yang diungkap oleh Maryati dan Priatna (2017) bahwa degradasi moral dan budaya telah menimpa bangsa ini, khususnya para pelajar Indonesia. Relevansi dengan penelitian ini yaitu penerapan budaya pada pembelajaran matematika untuk meningkatkan kemampuan koneksi matematika siswa. Ketika siswa belajar melalui budaya di lingkungan sekitar, maka akan memberikan andil terhadap kemampuan matematika lain yang dimiliki siswa. Kemampuan koneksi matematika dapat meningkat melalui model pembelajaran open ended berbantuan miniatur rumah adat Kudus.

Sari, dkk (2015) dalam penelitiannya menunjukkan hasil bahwa adanya peningkatan kemampuan koneksi matematis dan kemampuan berpikir kreatif siswa dengan menggunakan pembelajaran open ended dibandingkan dengan siswa yang memperoleh pembelajaran biasa atau konvensional. Relevansi dengan penelitian tindakan kelas ini yaitu untuk meningkatkan kemampuan koneksi matematika siswa, maka open ended sesuai untuk diterapkan.

Berdasarkan kekurangan yang dilakukan pada penelitian ahli sebelumnya, penelitian tindakan kelas ini dilakukan untuk mengatasi permasalahan dan meningkatkan kemampuan koneksi matematika melalui pembelajaran dengan model open ended 
sekaligus melestarikan budaya sekitar dan mengenalkannya pada proses pembelajaran.

Tujuan dari penelitian ini adalah untuk mendeskripsikan seberapa besar peningkatan kemampuan koneksi matematika siswa pada mata pelajaran matematika menggunakan model pembelajaran open ended berbantuan miniatur rumah adat Kudus pada siswa kelas IV SD 1 Gondosari Tahun pelajaran 2017/2018, untuk mendeskripsikan peningkatan keterampilan belajar siswa dalam mengidentifikasi hubungan antargaris menggunakan model konkret dengan menerapkan model open ended berbantuan miniatur rumah adat Kudus pada siswa kelas IV SD 1 Gondosari semester II tahun pelajaran 2017/2018, dan untuk mendeskripsikan keterampilan mengajar guru dalam menerapkan model pembelajaran open ended berbantuan miniatur rumah adat Kudus pada siswa kelas IV SD 1 Gondosari semester II tahun pelajaran 2017/2018.

Model pembelajaran open ended atau masalah terbuka yaitu suatu model dalam pembelajaran yang dimulai dengan memberikan masalah kepada siswa. Langkah-langkah model pembelajaran open ended yaitu menghadapkan siswa pada suatu masalah, siswa mengontruksikan ide untuk menemukan solusi, membiarkan siswa mencari solusi dengan berbagai cara, dan menyajikan hasil temuan. Kegiatan pembelajaran open ended membawa siswa dalam menjawab permasalahan melalui banyak cara dan banyak jawaban (yang benar) sehingga dapat meningkatkan intelektual dan pengalaman siswa dalam proses menemukan sesuatu yang baru.

Kemampuan koneksi matematika yaitu kemampuan mencari, memahami, dan menerapkan hubungan diantara ide-ide matematis yang saling berhubungan, dan membangun ide satu sama lain untuk menghasilkan keseluruhan yang saling terkait dalam ilmu matematika dan di luar konteks matematika serta menghubungkan mata pelajaran matematika dengan kehidupan sehari-hari.

Miniatur rumah adat Kudus merupakan media pembelajaran yang melibatkan pemanfaatan bentuk perwujudan budaya yang berkaitan dengan konsep atau prinsip dari suatu materi pembelajaran. Miniatur rumah adat Kudus adalah salah satu media pembelajaran yang menghadirkan budaya di sekitar, sebagai perantara materi hubungan antar garis pada bidang datar, juga sebagai pembelajaran yang mengenalkan dan melestarikan budaya sekitar. Bentuk konkret media miniatur rumah adat Kudus yaitu tiga dimensi atau mempunyai ruang di dalamnya. Media miniatur rumah adat Kudus terbuat dari kayu dan triplek. Kayu dan triplek tersebut dirangkai untuk membentuk sebuah miniatur rumah adat Kudus, kemudian setelah jadi triplek yang berfungsi sebagai sisi dari miniatur rumah adat Kudus tersebut dapat dilepas dan membentuk beberapa kerangka miniatur rumah adat Kudus untuk mempelajari materi hubungan antargaris pada bidang datar.

Keterampilan siswa dalam mengidentifikasi hubungan antargaris menggunakan model konkret yaitu kemampuan menggunakan akal atau fikiran dalam mengerjakan sesuatu yang menghasilkan sebuah karya dari pekerjaan dengan cara menemukan dan mengidentifikasi. Indikator kemampuan mengidentifikasi yaitu ketika siswa dapat menghubungkan rencana dengan strategi untuk menyelesaikan masalah, menggambarkan pemahaman materi, mencoba mengaplikasikan ide, mendemonstrasikan secara sistematis, memahami masalah, dan menentukan apa yang diketahui dan apa yang ditanyakan.

Keterampilan mengajar guru merupakan kompetensi pedagogik yang melibatkan berbagai kompetensi guru. Indikator keterampilan mengajar guru yaitu membuka pelajaran, memberikan permasalahan mengenai materi pelajaran, membimbing untuk membangun ide dari permasalahan yang diberikan, mengamati dan mengarahkan siswa dalam menyelesaikan permasalahan yang diberikan, menyampaikan hasil pekerjaan siswa di depan kelas, ketepatan mengelola waktu, dan menutup pelajaran.

Berdasarkan uraian di atas, kemampuan koneksi matematika siswa dapat meningkat melalui model pembelajaran open ended berbantuan miniatur rumah adat Kudus karena model pembelajaran open ended berbantuan miniatur rumah adat Kudus memungkin siswa untuk mengembangkan kemampuan koneksi matematika dan memberikan kesempatan untuk melakukan eksplorasi kemungkinan solusi yang akan digunakan dengan mengkoneksikan pengetahuan dan keterampilan matematika yang dimiliki.

\section{METODE PENELITIAN}

Penelitian yang dilakukan yaitu penelitian tindakan kelas (PTK). Penelitian tindakan kelas merupakan suatu tindakan yang dilakukan kepada siswa untuk menyelesaikan permasalahan yang sedang dihadapi. Model penelitian yang digunakan pada penelitian tindakan kelas ini yaitu menggunakan model Kemmis Taggard. Berdasarkan desain model PTK Kemmis Taggard tersebut penelitian ini 
dilakukan dalam dua siklus dengan melaksanakan empat tahapan pada setiap siklusnya, yaitu tahap rencana, aksi, observasi, dan refleksi. Tahap rencana menyiapkan perangkat pembelajaran dan instrumen yang dibutuhkan dalam penelitian telah disusun pada bulan November 2017 - Januari 2018, dan penelitian dilaksanakan pada bulan Februari 2018. Pada tahap kedua, guru melakukan pembelajaran dengan menerapkan model open ended berbantuan miniatur rumah adat Kudus untuk mempelajari materi hubungan antargaris pada bidang datar. Kegiatan observasi dilaksanakan bersama tahap aksi. Tahap refleksi dilakukan pada setiap akhir siklus untuk mengetahui, menganalisis, dan menilai proses pembelajaran yang telah dilakukan.

Penelitian tindakan kelas ini dilakukan kepada siswa kelas IV berjumlah 45 siswa di SD 1 Gondosari kecamatan Gebog kabupaten Kudus tahun pelajaran 2017/2018 semester II. Penelitian tindakan kelas ini dibatasi pada Kompetensi Inti 3 memahami pengetahuan faktual dengan cara mengamati (mendengar, melihat, membaca) dan menanya berdasarkan rasa ingin tahu tentang dirinya, makhluk ciptaan Tuhan dan kegiatannya, dan benda-benda yang dijumpai di miniatur rumah, sekolah, dan tempat bermain, serta kompetensi ini 4 yaitu menyajikan pengetahuan faktual dalam bahasa yang jelas, sistematis, dan logis, dalam karya yang estetis, dalam gerakan yang mencerminkan anak sehat, dan dalam tindakan yang mencerminkan perilaku anak beriman dan berakhlak mulia. Kompetensi Dasar 3.10 menjelaskan hubungan antar garis (sejajar, berpotongan, berhimpit) menggunakan model konkret dan 4.10 mengidentifikasi hubungan antargaris (sejajar, berpotongan, berhimpit) menggunakan model konkret.

Teknik pengumpulan data dalam penelitian ini yaitu dengan tes, wawancara, observasi, dan dokumentasi. Tes dikerjakan oleh peserta tes (siswa kelas IV secara perorangan) sehingga menghasilkan skor tentang kemampuan koneksi matematika peserta tes, yang dibandingkan dengan nilai KKM yang telah ditetapkan. Berbagai pertanyaan disiapkan dalam pedoman wawancara untuk mendapatkan informasi melalui metode wawancara. Model penelitin tindakan kelas ini disajikan pada gambar 1.

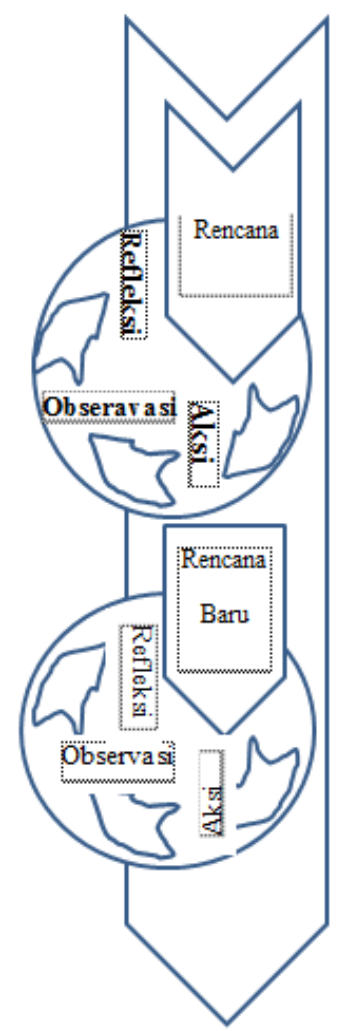

Gambar 1. Penelitian Tindakan Model Kemmis Taggard

\section{HASIL DAN PEMBAHASAN}

Data hasil penelitian diperoleh dari hasil tes kemampuan koneksi matematika siswa, hasil pengamatan keterampilan mengajar guru, dan hasil pengamatan keterampilan belajar siswa dalam mengidentifikasi hubungan antargaris menggunakan model konkret. Data-data tersebut kemudian dianalisis dan disajikan dalam bentuk deskripsi sebagai gambaran hasil penelitian. Hasil belajar kemampuan koneksi matematika pada penelitian tindakan kelas dapat dilihat di Tabel 1.

Tabel 1. Hasil Belajar Kemampuan Koneksi Matematika

\begin{tabular}{ccc}
\hline Tahap & Rata-Rata & Kriteria \\
\hline Siklus I & 63,3 & Perlu Bimbingan (D) \\
Siklus II & 78,2 & Cukup (C) \\
\hline
\end{tabular}

Rata-rata kemampuan koneksi matematika siswa pada siklus II lebih dari siklus I. Hal ini menunjukkan bahwa adanya peningkatan ratarata kemampuan koneksi matematika dari siklus I ke siklus II. Terdapat 6 siswa yang belum mengalami peningkatan kemampuan koneksi matematika.

Pada akhir siklus I, guru memberikan evaluasi berupa tes tertulis dengan 10 soal uraian pada materi hubungan antargaris pada bidang 
datar dengan perolehan nilai rata-rata klasikal 63,33. Dengan demikian nilai rata-rata klasikal siswa pada siklus I belum memenuhi indikator keberhasilan yaitu minimal $75 \%$, sehingga penelitian dilanjutkan pada siklus II. Dari 45 siswa terdapat 26 siswa yang belum mampu mencapai nilai KKM atau tidak tuntas. 26 siswa tersebut belum mampu mencapai KKM karena siswa kurang teliti dalam mengerjakan soal siklus I yang diberikan guru. Dari 10 soal evaluasi siklus I mereka hanya memperoleh skor maksimal 5-7 soal saja. Siswa sulit memahami soal meskipun guru telah memberikan pengarahan kepada mereka. Hal tersebut senada dengan pendapat yang dikemukakan oleh Mullis dkk (2015) bahwa hasil TIMMS 2015 menunjukkan siswa di Indonesia menguasai soalsoal yang bersifat rutin, serta mengukur pengetahuan akan fakta keseharian, tetapi lemah pada konten kognitif geometri, number, menyajikan, memahami, mengaplikasikan, dan menganalisis.

Pada pembelajaran siklus I, terdapat temuan bahwa 5 siswa belum memahami dengan tepat materi hubungan antargaris pada bidang datar. Hal ini terlihat ketika guru menunjukkan sebuah miniatur rumah adat Kudus dan bertanya kepada siswa dimanakah letak garis sejajar pada miniatur rumah adat Kudus tersebut? siswa tersebut masih kebingungan saat menunjukkannya. Beberapa siswa terlihat merasakan bosan pada pelajaran matematika karena saat kegiatan diskusi berlangsung, siswa kurang aktif pada kegiatan kelompok.

Persentase kemampuan koneksi matematika siswa juga mengalami peningkatan dari siklus I ke siklus II yaitu dari $31,11 \%$ menjadi 93,33\% dengan kriteria sangat baik (A). Hal ini menunjukkan bahwa hasil tersebut telah memenuhi uji hipotesis yang telah ditetapkan dan telah mencapai indikator keberhasilan yaitu minimal mencapai persentase ketuntasan sebesar $75 \%$ dengan kriteria cukup (C).

Ketuntasan belajar kemampuan koneksi matematika siswa menunjukkan peningkatan dari siklus I ke siklus II. Peningkatan dari siklus I ke siklus II mencapai $62,22 \%$. Hal ini menunjukkan bahwa penerapan model open ended mampu meningkatkan kemampuan koneksi matematika siswa materi hubungan antargaris pada bidang datar. Berdasarkan Tabel 1, hasil penelitian telah mencapai target yang ditentukan pada indikator keberhasilan dengan memperoleh ketuntasan belajar klasikal minimal $75 \%$.

Pada siklus I, nilai rata-rata setiap indikator kemampuan koneksi matematika siswa masih di bawah nilai KKM, namun rata-rata setiap indikator meningkat pada siklus II. Kemampuan pada indikator memahami hubungan antar topik matematika mengalami peningkatan pada setiap siklusnya. Akan tetapi skor rata-rata yang diperoleh masih di bawah rata-rata klasikal, karena siswa sering lupa memberikan nama saat menghubungkan pada materi bidang datar. Siswa langsung pada penyelesaian masalah dan tidak teliti dalam menghubungkan ke topik matematika lain. Guru sudah membimbing siswa dalam memahami antar topik matematika yang dipelajari. Namun salah satu fakor internal yang membuat perolehan skor rata-rata di bawah rata-rata klasikal yaitu kepercayaan diri yang dimiliki siswa. Menurut Rahmawati (2016: 9), hanya $23 \%$ siswa di Indonesia yang memiliki percaya diri terhadap kemampuan matematika yang dimilikinya. Rata-rata setiap indikator kemampuan koneksi matematika siklus I dan II dapat dilihat pada tabel 2 .

Tabel 2. Rata-Rata Setiap Indikator Kemampuan Koneksi Matematika

\begin{tabular}{ccccc}
\hline \multirow{2}{*}{ Indikator } & \multicolumn{2}{c}{ Siklus I } & \multicolumn{2}{c}{ Siklus II } \\
\cline { 2 - 5 } & Skor Rata-Rata & Kategori & Skor Rata-Rata & Kategori \\
\hline 1. & 48,67 & Perlu Bimbingan (D) & 76,22 & Cukup (C) \\
2 & 74 & Perlu Bimbingan (D) & 75,78 & Cukup (C) \\
3 & 72 & Perlu Bimbingan (D) & 90,44 & Cukup (C) \\
4 & 67,19 & Perlu Bimbingan (D) & 76 & Baik (B) \\
5 & 62,67 & Perlu Bimbingan (D) & Cukup (C) \\
6 & 55,89 & Perlu Bimbingan (D) & 82,89 & Cukup (C) \\
\hline
\end{tabular}

Pada Tabel 2. dapat dilihat bahwa semua menunjukkan bahwa terjadi peningkatan skor rata-rata indikator koneksi matematika mengalami peningkatan. Hasil tes mengenai kemampuan koneksi matematika siswa menggunakan model open ended berbantuan miniatur rumah adat Kudus pada pembelajaran matematika materi hubungan antargaris pada bidang datar pada kelas IV SD 1 Gondosari kemampuan koneksi matematika siswa dari siklus I ke siklus II.

Kekurangan pada siklus I perlu adanya perbaikan. Salah satu perbaikan yang dilakukan yaitu guru yaitu menggali pengetahuan prasyarat siswa tentang materi hubungan antargaris pada bidang datar dengan melakukan tanya jawab 
berkaitan miniatur rumah adat Kudus. Ibrahim dan Suparni (2012) menjelaskan bahwa guru harus menyiapkan dan memiliki kerangka kerja yang baik dalam mengelola pembelajaran, dan memberikan banyak saran serta tuntunan agar siswa dapat mengembangkan ilmunya. Selain itu, menurut penelitian Ulya dan Rahayu (2017) bahwa cara untuk meningkatkan aktivitas siswa dalam belajar matematika yaitu dengan memberikan pembelajaran yang menarik seperti permainan dan sebagainya.

Keterampilan belajar siswa merupakan hal yang penting dalam pembelajaran. Pembelajaran dianggap bermakna jika dalam proses pembelajaran tersebut siswa mempunyai keterampilan untuk mencari dan menghubungkan sendiri penyelesaian masalah serta membangun sendiri pengetahuan baru melalui pengalaman langsung. Hasil belajar yang diperoleh siswa tergantung pada seberapa banyak siswa melakukan keterampilan belajar. Semakin banyak keterampilan belajar yang dilakukan oleh siswa akan membuat pembelajaran lebih hidup, dinamis dan tidak monoton. Keterampilan belajar siswa akan terlaksana dan menunjukkan hasil yang baik apabila guru melakukan perencanaan yang sistematis dan terarah.

Yuliani, Kanzunnudin, dan Rahayu (2018) menyatakan kegiatan pembelajaran akan menciptakan suasana yang menyenangkan, nilai siswa menjadi optimal, serta dapat menumbuhkembangkan kemampuannya ketika guru menerapkan model pembelajaran. Salah satu macam model pembelajaran yakni model open ended. Model pembelajaran open ended dapat membuat siswa memiliki keterampilan mengidentifikasi hubungan antargaris melalui model konkret. Sejalan dengan Ambarwati dan Muqdamien (2016:222) yang menyatakan bahwa setelah belajar orang memiliki keterampilan, pengetahuan, sikap dan nilai.

Data hasil observasi keterampilan siswa dalam mengidentifikasi hubungan antargaris menggunakan model konkret menunjukkan pada siklus II diperoleh skor ratarata 3,19 dengan kriteria baik. Pada siklus I memperoleh rata-rata 2,33 dengan kriteria cukup baik dan meningkat pada siklus II. Siswa lebih senang dan terampil mengungkapkan pendapatnya. Hal ini terlihat ketika guru menyajikan masalah melalui miniatur rumah adat Kudus, siswa tertarik dalam mengikuti pembelajaran karena mereka terlibat secara langsung. Siswa juga sudah tidak mengalami kesulitan dalam membangun konsep hubungan antargaris pada bidang datar karena sudah memperoleh pengalaman dari kegiatan pembelajaran pada siklus I. Kerjasama siswa dalam kelompok juga sudah baik, tidak ada siswa yang mendominasi dalam menyelesaikan tugas kelompok, siswa yang pandai membantu siswa yang kurang pandai.

Keterampilan belajar siswa pada siklus II lebih baik dari siklus I. Hal ini menunjukkan bahwa terdapat peningkatan keterampilan belajar siswa dari siklus I ke siklus II. 5 siswa mengalami belum mengalami peningkatan. Meskipun tidak meningkat, keterampilan belajar siswa berada dalam kriteria baik.

Guru memiliki kedudukan yang penting dalam mewujudkan tujuan pembelajaran. Keterampilan guru dalam mengajar dan mengelola pembelajaran yang dikemas secara kreatif sangat dibutuhkan untuk memacu siswa agar lebih giat belajar. Guru dituntut untuk dapat menciptakan suasana belajar yang tak hanya aktif dan menyenangkan saja, melainkan juga pembelajaran yang efektif dan efisien. Hal yang perlu digaris bawahi adalah, siswa merupakan individu yang unik dimana mereka mempunyai karakteristik dan gaya belajar masing-masing, sehingga sangat penting bagi guru memberikan kesempatan pada siswa untuk belajar sesuai dengan kemampuan pada dirinya.

Hasil observasi keterampilan mengajar guru menunjukkan keterampilan mengajar guru mengalami peningkatan dari siklus I ke siklus II. pada siklus I keterampilan mengajar guru memperoleh rata-rata 3,59 dengan kriteria sangat baik. Pada siklus II guru memperbaiki kekurangan-kekurangan yang ada pada pelaksanaan siklus I. Hasil observasi keterampilan guru pada siklus II menunjukkan skor rata-rata 3,82 termasuk dalam kriteria sangat baik. Hal ini menunjukkan bahwa adanya peningkatan keterampilan guru pada siklus I ke siklus II. Keterampilan mengajar guru pada siklus II sudah termasuk dalam indikator keberhasilan yang ditentukan karena sudah pada kriteria baik. Upaya perbaikan yang dilakukan guru, dapat dikatakan berhasil mengingat adanya peningkatan keterampilan guru seperti yang telah dijelaskan.

Pada pembelajaran siklus I, beberapa siswa masih lemah dalam menyelesaikan masalah dalam proses membangun konsep hubungan antargaris pada bidang datar. Siswa juga masih kesulitan dalam menarik kesimpulan dari konsep hubungan antargaris pada bidang datar terkait dengan kehidupan sehari-hari. Terdapat salah satu siswa yang selama mengikuti proses pembelajaran selalu menghadap ke depan seolah-olah sedang memperhatikan guru namun pandangannya terlihat kosong dan tidak 
semangat, terkadang ia juga menundukkan kepala. Bintoro dan Zuliana (2013:154) menjelaskan bahwa kontruksi pengetahuan akan lebih mudah jika berangkat dari pengalaman nyata yang dekat dengan siswa, terkait dengan realitas, mudah dibayangkan (imagineable), berwujud suatu kegiatan dan kebiasaaan yang sering dilakukan di lingkungan atau di daerah sekitarnya. Dengan menggunakan model open ended dan miniatur rumah adat Kudus, siswa dapat melewati proses pembelajaran dengan baik. Dengan demikian inti dari pembelajaran matematika adalah dapat menggunakannya untuk menyelesaikan permasalahan sehari-hari. Sementara itu menurut Darmayanti, dkk (2014:2) mengungkapkan dalam pembelajaran di sekolah dasar, seorang anak harus ditanamkan konsep secara aktif sehingga pembelajaran tersebut lebih bermakna. Hal ini berarti bahwa proses pembelajaran harus dilakukan dengan kegiatan yang sering dilakukan di daerah sekitarnya untuk menanamkan konsep dengan pengalamannya sendiri. Proses tersebut merupakan proses dimana siswa dapat mengkoneksikan konsep matematika dalam kehidupan sehari-hari.

Dilihat dari permasalahan pada siklus I, masih ada permasalahan siswa dalam mengkoneksikan konsep. Menurut Anita (2014:126) tahap awal kemampuan yang harus dikuasai siswa adalah kemampuan mengkoneksikan konsep secara matematis yang pada akhirnya kemampuan koneksi matematis ini menjadi prasyarat siswa dapat menguasai kemampuan-kemampuan lain yang lebih tinggi. Berdasarkan kesulitan yang dialami siswa menyebabkan kemampuan koneksi matematika siswa rendah sehingga nilai yang diperoleh belum mencapai KKM.

Pada data hasil observasi keterampilan siswa dalam mengidentifikasi hubungan antargaris menggunakan model konkret pada siklus II diperoleh skor rata-rata 3,19 dengan kriteria baik. Siswa lebih senang dan terampil mengungkapkan pendapatnya.Siswa yang menerapakan model open ended pasti dapat memecahkan masalah dan memberikan beberapa kemajuan bagi siswa yaitu membantu dalam mengidentifikasi miskonsepsi siswa, sehingga dapat mengembangkan keterampilan yang dimiliki siswa (Al-Absi, 2012: 350).

Keterampilan mengajar guru pada siklus II sudah termasuk dalam indikator keberhasilan yang ditentukan karena sudah pada kriteria baik. Upaya perbaikan yang dilakukan guru, dapat dikatakan berhasil mengingat adanya peningkatan keterampilan guru seperti yang telah dijelaskan. Guru sebagai tenaga pengajar dan pendidik harus selalu meningkatkan kualitas pengajaran dan pembelajaran di kelas yaitu dengan melibatkan siswa secara aktif dan efektif dalam proses belajar mengajar sesuai dengan penerapan kurikulum 2013 (Biliya, 2015). Pernyataan tersebut sependapat dengan Nugroho, dkk (2017) yang menyatakan bahwa guru harus mengajar atau menyampaikan materi pelajaran dengan bagus, informatif, dan up to date.

Mengajar merupakan tugas pokok seorang guru yang membutuhkan keterampilan dan karakteristik. Sebagaimana yang telah dijelaskan oleh Feronita dkk (2015) bahwa tugas guru sebagai seorang pengajar atau guru harus mempunyai beberapa karakteristik dalam mengajar. Karakteristik tersebut adalah guru sebagai pusat mengajar, meminta dengan tegas, dan menanamkan nilai.

\section{SIMPULAN}

Berdasarkan hasil penelitian tindakan kelas yang telah dilakukan, disimpulkan bahwa penerepan model open ended berbantuan miniatur rumah adat Kudus dapat meningkatkan koneksi matematika siswa pada materi hubungan antargaris pada bidang datar.keterampilan belajar siswa dan keterampilan guru dalam pengelolaan pembelajaran.

\section{UCAPAN TERIMAKASIH}

Penulis ucapkan terimakasih kepada segenap Tim Pengelola Jurnal Anargya yang telah memberi kesempatan untuk mempublikasikan karya ilmiah.

\section{DAFTAR PUSTAKA}

Al-Absi, M. 2012.The Effect of Open-Ended Tasks -as an Assessment Tool- on Fourth Graders' Mathematics Achievement, and Assessing Students' Perspectives about it. Jordan Journal of Educational Sciences, 9 (3): 345-351.

Ambarwati, Tiara dan Muqdamien, Birru. 2016. Peningkatan Hasil Belajar Siswa dalam Menyelesaikan Soal Cerita Bangun Ruang pada Pelajaran Matematika melalui Pendekatan Open Ended. Primary, 08 (02), 221-232.

Anita, I. W. 2014. Pengaruh Kecemasan Matematika (Mathematics Anxiety) terhadap Kemampuan Koneksi Matematis Siswa SMP.Jurnal Ilmiah Program Studi Matematika STKIP Silawangi Bandung, 3 (1), 125-132.

Biliya, B. 2015. Penerapan Model Open Ended untuk Meningkatkan Keterampilan Proses dan Hasil Belajar Siswa Kelas V SDN 1 

Repaking - $\quad$ Wonosegoro -
Boyolali.Scholaria, 5 (1), 78- 91.

Bintoro, H. S. dan Zuliana, E. 2013. Pembelajaran Matematika Materi Luas Trapesium Dengan Pendekatan Luas Persegi Panjang Menggunakan Model Pembelajaran Matematika Realistik Berkonteks Rumah Adat Kudus. Dimuat dalam prosiding SNMPM Universitas Sebelas Maret. Universitas Sebelas Maret. Solo, Maret 2013.

Darmayanti., Putra dan Suara. 2014. Model Open Ended Berbasis Reirforcement Berpengaruh Terhadap Hasil Belajar IPS Siswa Kelas V SDN 18 Dangin Puri Denpasar Utara. Jurnal Mimbar PGSD Universitas Pendidikan Ganesha, 2 (1).

Daryanto. 2013. Inovasi Pembelajaran Efektif. Bandung: Yrama Widya.

Feronita, A., Harnanik, dan Marimin. 2015. Pengaruh Keterampilan Mengajar Guru dan Lingkungan Keluarga Terhadap Belajar Siswa. Economic Education Analisys Journal, 4 (2): 256-263.

Huda, M. 2013. Model-model Pengajaran dan Pembelajaran. Yogyakarta: Pustaka Pelajar.

Ibrahim dan Suparni. 2012. Pembelajaran Matematika Teori dan Aplikasinya. Yogyakarta: Suka-Press UIN Sunan Kalijaga.

Kumalasari, A. dan Putri, R. O. P. E. 2013.Kesulitan Belajar Matematika Siswa ditinjau dari Segi Kemampuan Koneksi Matematika.Prosiding seminar nasional matematika dan pendidikan matematika. Universitas Negeri Yogyakarta,7-14.

Mardiah, M., Widyastuti, R., dan Rinaldi, A. 2018. Pengembangan Modul Pembelajaran Matematika Berbasis Etnomatematika Menggunakan Model Inkuiri. Desimal: Jurnal Matematika, 1 (2): 119-126.

Maryati, I. dan Priatna, N. 2017. Integrasi NilaiNilai Karakter Matematika Melalui Pembelajaran Kontekstual. Jurnal Mosharafa, 6 (3): 333-344.

Mullis dkk. 2015. TIMMS 2015 International Result in Mathematics. (pdf). (timss2015.0rg. pdf, diakses tanggal 2 November 2017).

Noviarny, D. A., Murtono, dan Ulya, H. 2018. Model Think Talk Write Berbantuan Media Monomat Meningkatkan Kemampuan Komunikasi Matematika Siswa Sekolah Dasar. ANARGYA: Jurnal
Ilmiah Pendidikan Matematika, 1 (1): 2128.

Nugroho, A. A. dkk. 2017. Pengembangan Blog Sebagai Media Pembelajaran Matematika. Al-Jabar: Jurnal Pendidikan Matematika, 8 (2): 197-203.

Rahmawati. 2016. Hasil TIMSS 2015. (Online), (http://puspendik.kemendikbud.go.id/semi nar/upload/RahmawatiSeminar\%20Hasil \%20TIMSS\%202015.pdf, diakses tanggal 3 November 2017).

Sari, L. N. I., Syahputra, E. dan Asmin.2015. Peningkatan Kemampuan Koneksi Matematis dan Berpikir Kreatif Siswa Melalui Pembelajaran Open Ended di SMP Muhammadiyah 03 Medan.Jurnal Tabularasa PPS Unimed, 12 (1): 1-11.

Sumarmo, U. 2013. Berpikir dan Disposisi Matematika serta Pembelajarannya. Bandung: FPMIPA - UPI.

Ulya, H. 2016. Pembelajaran Matematika Berbasis Etnomatematika untuk Membangun Karakter Cinta Tanah Air dan Kreativitas Belajar Matematika.Prosiding Seminar Nasional Psikologi Universitas Muria Kudus, 2939.

Ulya, H. dan Rahayu, R. 2017. Increasing Primary School Students' Attitude Toward Mathematics Through The Implementation Of Treffinger Learning Using Dakon Game. International Conference On Education, 1 (01): 1-7.

Ulya, H. dan Rahayu, R. 2018. Analisis Kebutuhan Perangkat Pembelajaran Open Ended Berbasis Keunggulan Lokal Kudus untuk Meningkatkan Kemampuan Representasi Matematis. Prosiding Seminar Nasional "Penguatan Pendidikan Karakter Pada Siswa Dalam Menghadapi Tantangan Global”, 172177.

Ulya, H. dan Rahayu, R. 2018.Uji Kelayakan Perangkat Pembelajaran Open-Ended Berbasis Etnomatematika Ditinjau dari Gaya Kognitif Siswa. Journal of Medives: Journal of Mathematics Education IKIP Veteran Semarang, 2 (2): 183-194.

Yuliani, I., Kanzunnudin, M., dan Rahayu, Ratri. 2018. Penerapan Model Creative Problem Solving Berbantuan Media Bongkar Pasang untuk Meningkatkan Berpikir Kreatif Matematika. Anargya: Jurnal Ilmiah Pendidikan Matematika, 1 (1): 2936. 
